\title{
Impact of Burning and Grazing on Soil Water Patterns in the Pinyon-Juniper Type
}

\author{
GERALD F. GIFFORD
}

\section{Abstract}

Soil water patterns were studied from June 1973 to February of 1977 in pinyon-juniper woodland, on pinyon-juniper areas chained and windrowed (grazed and ungrazed), and on pinyon-juniper areas chained with debris-in-place (ungrazed; burned vs. unburned). The pinyon-juniper woodland always had the least soil water, regardless of the season. Grazing did not affect soil water patterns on the chained with windrowing treatment. Burning of debris on the debris-in-place treatment had little impact on water the first year, but significantly more water was measured on the burned treatment at the beginning of the second year. Soil water patterns previously established between the unburned debris-inplace and ungrazed windrowed treatment changed in August, 1974, and the two treatments were equivalent for the balance of the study. Prior to August of 1974 the unburned debris-in-place treatment had always had more soil water than the ungrazed windrowed treatment. These changes were attributed to possibly milder winters with decreased snowfall.

As previously indicated by Gifford and Shaw (1973) and Gifford (1975), soil water patterns as influenced by vegetation manipulation practices have not received a great deal of attention in the pinyon-juniper (Pinus edulis-Juniperus osteosperma) type. No studies involving direct measures of soil water have been reported that relate effects of either grazing or burning of debris. Roundy et al. (1978) report that burning of pinyon-juniper in eastern Nevada is not expected to increase runoff or soil loss substantially on sites with coarse-textured soils. Buckhouse and Gifford (1976) found that initial impacts of grazing and burning on a chained pinyonjuniper site in southeastern Utah resulted in somewhat decreased infiltration rates. Long-term impacts were not defined, however.

The study discussed here represents an expansion of soil water investigations initiated in 1970 in southeastern Utah. The objective of this study phase was to determine the effect on soil water patterns of burning pinyon-juniper debris on a chained with debris-in-place site (no grazing), and of grazing on a chained and windrowed site. Concerning soil water patterns prior to the initiation of the grazing and burning aspects, Gifford and Shaw (1973) stated:

Results. . indicate the greatest moisture accumulation occurred under the debris-in-place treatment (as compared to woodland controls),. . .regardless of season. ... The woodland had the least soil moisture throughout most of each year. Most moisture flux took place in the upper $60-$ to- $90 \mathrm{~cm}$ of soil profile, with only minor changes occurring at greater depths. Differences in soil moisture patterns are due in part to differences in microclimates due to chaining, different rooting depths and length of growing season, mulching effect of litter on the debris-in-place treatment, and possible differences in snow accumulation.

Author is professor and chairman, Watershed Science Unit, Range Science Department, College of Natural Resources, Utah State University, Logan, 84322.

This study was conducted in cooperation with the Utah Agricultural Experiment Station (Project 749) and the USDI, Office of Water Research and Technology, under PL88-379, Project No. A-022-Utah, Agreement No. 14-34-0001-6046, as authorized under the Water Resources Research Act of 1964, as amended. Journal paper 2662, Utah Agricultural Experiment Station, Utah State University, Logan, 84322.

Manuscript received January $28,1981$.

\section{Site Description and Methods}

The study site is within the Colorado Plateau about $70 \mathrm{~km}$ west of Blanding, Utah, in the N.E. 1/4 of S.W. 1/4 of T38S., R18E, near Coyote Flat at an elevation of about $2,150 \mathrm{~m}$. The soils are derived from primarily sandstone and are of the Aridic ArgiustollsTypic Argiustrolls association. The soil profile depth is $1.5 \mathrm{~m}$, and soil texture is primarily sandy loam with few, if any, rocks present. The $\mathrm{pH}$ ranges from 7.7 to 8.1 . The canopy cover of mature juniper ( 500 trees/ha) and pinyon ( 200 trees/ha) averages 24 and $8 \%$, respectively. Shrub cover is less than $1 \%$ and consists of big sagebrush. Bare ground and litter make up the balance. The bare ground category includes some cryptogam species present in the surface $3 \mathrm{~cm}$ of soil.

During the study period, the chaining-with-debris-in-place treatment at Blanding had a ground cover consisting primarily of 25 to $45 \%$ bare ground, 30 to $60 \%$ litter, and 12 to $20 \%$ crested wheatgrass. The chain-with-windrowing treatment had from 40 to $65 \%$ bare ground, 15 to $30 \%$ litter, and 17 to $25 \%$ crested wheatgrass cover.

Initial chaining treatments occurred in the fall of 1967. The windrowed treatments were drill seeded to crested wheatgrass (Agropyron cristatum) at $9.1 \mathrm{~kg} / \mathrm{ha}$ and the debris-in-place treatment was broadcast seeded at the same rate to crested wheatgrass. The entire study area was then fenced to exclude livestock.

Secondary treatment (controlled burning) was applied to a portion of the debris-in-place treatment on September 5, 1974. A clean burn was produced with most of the fuel being consumed within 2 to 3 hours. Grazing remained excluded from this area.

During late May and early June, 1974, cattle were stocked on portions of the chained with debris windrowed treatment at the rate of 2 ha/AUM. This represented the first grazing since the 1967 chaining. Crested wheatgrass on the windrowed area was utilized $55 \%$ during the spring of $1974,78 \%$ during the spring of 1975 , and $66 \%$ during the spring of 1976 . Utilization was determined at the close of each spring grazing period through clipping, using exclosure as control units.

Techniques for measuring soil water have previously been described (Gifford and Shaw 1973). The number of soil moisture access tubes monitored within each treatment included 15 in the woodland, 14 in the grazed windrow area, 6 in the ungrazed windrow exclosures, 9 in the burned debris-in-place area, and 6 in the unburned debris-in-place treatment.

Precipitation amounts received during the study period are given in Table 1.

\section{Results and Discussion}

Soil water patterns (Table 2 and Fig. 1 and 2) initially followed a trend similar to that already described by Gifford and Shaw (1973). The unburned debris-in-place treatment continued to evidence the greatest moisture accumulation among all treatments throughout the year until August of 1974. At that time, the soil moisture differences that had existed the previous 4 years between the 
Table 1. Precipitation (cm) for Blanding study site.1

\begin{tabular}{|c|c|c|c|}
\hline Date & Amount & Date & Amount \\
\hline $12-2-72$ to $1-28-73$ & 13.8 & $8-8-76$ & 0.1 \\
\hline $1-28-73$ to $4-11-73$ & 6.2 & $8-17-76$ & 0.2 \\
\hline $4-11-73$ to $7-4-73$ & 6.9 & $8-23-76$ & 0.1 \\
\hline $7-16-73$ & 0.2 & $8-29-76$ & 0.1 \\
\hline $7-18-73$ & 1.3 & $9-18-76$ & 0.3 \\
\hline $7-20-73$ & 0.4 & $9-21-76$ & 0.3 \\
\hline $7-27-73$ & 0.2 & $9-23-76$ & 0.1 \\
\hline $8-17-73$ & 0.6 & $9-24-76$ & 0.2 \\
\hline $8-20-73$ & 0.3 & $9-25-76$ & 0.6 \\
\hline $8-21-73$ & 0.2 & $9-26-76$ & 0.2 \\
\hline $8-27-73$ & 0.2 & $10-2-76$ & 0.3 \\
\hline $8-29-73$ & 1.1 & $11-3-76$ to $12-17-76$ & 0.2 \\
\hline $9-10-73$ & 1.0 & $12-17-76$ to $2-4-77$ & 2.5 \\
\hline $9-10-73$ to $6-16-74$ & 16.0 & & \\
\hline $7-15-74$ & 0.2 & & \\
\hline $7-16-74$ & 2.1 & & \\
\hline $7-18-74$ & 0.4 & & \\
\hline $8-2-74$ & 1.1 & & \\
\hline $9-14-74$ & 0.4 & & \\
\hline $9-15-74$ & 0.3 & & \\
\hline $9-24-74$ to $6-14-75$ & 27.0 & & \\
\hline $6-19-75$ & 0.3 & & \\
\hline $7-9-75$ & 1.4 & & \\
\hline $7-16-75$ & 1.4 & & \\
\hline $7-26-75$ & 0.1 & & \\
\hline $7-28-75$ & 0.3 & & \\
\hline $7-29-75$ & 1.6 & & \\
\hline $8-10-75$ & 0.4 & & \\
\hline $8-12-75$ & 0.4 & & \\
\hline $8-20-75$ & 0.1 & & \\
\hline $8-21-75$ & 1.1 & & \\
\hline $9-4-75$ & 0.4 & & \\
\hline $9-15-75$ & 0.5 & & \\
\hline $9-18-75$ & 0.1 & & \\
\hline $9-27-75$ to $6-6-76$ & 10.2 & & \\
\hline $6-7-76$ & 0.1 & & \\
\hline $7-9-76$ & 0.2 & & \\
\hline $7-17-76$ & 0.1 & & \\
\hline $7-18-76$ & 0.1 & & \\
\hline $7-25-76$ & 1.7 & & \\
\hline $7-26-76$ & 0.6 & & \\
\hline $7-27-76$ & 0.3 & & \\
\hline $7-30-76$ & 1.4 & & \\
\hline
\end{tabular}

'Recording gages in operation from about June 10 to approximately October 1 of each year: storage gages operated during winter period.

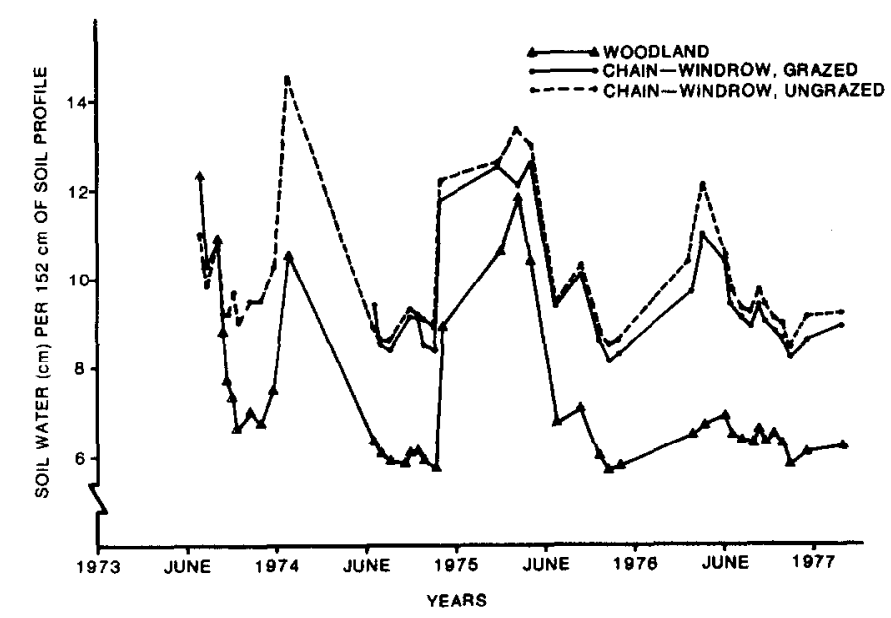

Fig. 1. Soil water patterns in native pinyon-juniper woodland and in grazed and ungrazed chain with windrowing treatments.
Table 2. Total centimeters of water per $152 \mathrm{~cm}$ of soil profile on various dates at Blanding study site.'

\begin{tabular}{|c|c|c|c|c|c|}
\hline \multirow[b]{2}{*}{ Date } & \multirow[b]{2}{*}{ Woodland ${ }^{2}$} & \multicolumn{2}{|c|}{ Chain-wind row } & \multicolumn{2}{|c|}{ Chain-debris-in-place } \\
\hline & & Grazed $^{3}$ & Ungrazed $^{4}$ & Burned $^{5}$ & Unburned ${ }^{4}$ \\
\hline $6-21-73$ & $12.31^{\mathrm{a}}$ & & $10.97^{\circ}$ & & $14.97^{b}$ \\
\hline $7-6-73$ & $10.25^{b}$ & & $9.82^{\mathrm{a}}$ & & $12.63^{\mathrm{b}}$ \\
\hline $7-19-73$ & $10.81^{\mathrm{a}}$ & & $10.92^{\mathrm{a}}$ & & $13.79^{\mathrm{b}}$ \\
\hline $8-1-73$ & $8.75^{\mathrm{a}}$ & & $9.19^{8}$ & & $13.19^{\mathrm{b}}$ \\
\hline $8-16-73$ & $7.67^{\mathrm{a}}$ & & $9.16^{\mathrm{a}}$ & & $12.70^{\mathrm{b}}$ \\
\hline $9-13-73$ & $7.35^{a}$ & & $9.66^{b}$ & & $13.32^{\circ}$ \\
\hline $9-24-73$ & $6.63^{\mathrm{a}}$ & & $8.95^{b}$ & & $12.69^{c}$ \\
\hline $10-19-73$ & $7.02^{\mathrm{a}}$ & & $9.48^{\mathrm{b}}$ & & $13.11^{c}$ \\
\hline $11-24-73$ & $6.72^{\mathrm{a}}$ & & $9.50^{b}$ & & $13.70^{\circ}$ \\
\hline $12-18-73$ & $7.46^{\mathrm{a}}$ & & $10.30^{b}$ & & $13.76^{\mathrm{C}}$ \\
\hline $1-2 G-74$ & $10.47^{a}$ & & $14.53^{\mathrm{b}}$ & & - \\
\hline $6-16-74$ & $6.38^{\mathrm{a}}$ & $9.41^{b c}$ & $8.94^{\mathrm{b}}$ & & $11.31^{\mathrm{c}}$ \\
\hline $6-28-74$ & $6.09^{\circ}$ & $8.52^{b}$ & $8.64^{\mathrm{b}}$ & & $10.90^{c}$ \\
\hline $7-11-74$ & $5.95^{\mathrm{a}}$ & $8.40^{\mathrm{b}}$ & $8.58^{\mathrm{b}}$ & & $10.53^{c}$ \\
\hline $7-24-74$ & $5.87^{a}$ & - & - & & $10.71^{\mathrm{b}}$ \\
\hline $8-5-74$ & $6.12^{a}$ & $9.07^{b}$ & $9.28^{b}$ & & $10.61^{b}$ \\
\hline $8-22-74$ & $6.16^{\mathrm{a}}$ & $9.10^{\mathrm{b}}$ & $9.17^{b}$ & & $10.41^{\mathrm{b}}$ \\
\hline $9-18-74$ & $5.96^{\mathrm{a}}$ & $8.51^{\mathrm{b}}$ & $9.08^{b}$ & $11.20^{\mathrm{c}}$ & $9.78^{b c}$ \\
\hline $10-20-74$ & $5.83^{a}$ & $8.41^{b}$ & $8.93^{\circ}$ & $10.84^{\circ}$ & $9.63^{\text {be }}$ \\
\hline $11-30-74$ & $8.91^{\mathrm{a}}$ & $11.78^{\mathrm{b}}$ & $12.25^{b}$ & $14.23^{c}$ & $12.36^{b}$ \\
\hline $3-37-75$ & $10.63^{\mathrm{a}}$ & $12.49^{b}$ & $12.55^{\mathrm{b}}$ & $15.44^{c}$ & $15.08^{c}$ \\
\hline $4-12-75$ & $11.83^{\mathrm{a}}$ & $12.09^{\mathrm{ab}}$ & $13.27^{\mathrm{bc}}$ & $14.49^{c}$ & $13.08^{\mathrm{b}}$ \\
\hline $5-10-75$ & $10.39^{n}$ & $12.62^{\mathrm{b}}$ & $12.95^{\mathrm{b}}$ & $14.54^{\mathrm{c}}$ & $13.65^{\text {bc }}$ \\
\hline $6-24-75$ & $6.75^{\mathrm{a}}$ & $9.28^{b}$ & $9.41^{b}$ & $10.64^{c}$ & $9.66^{\mathrm{bc}}$ \\
\hline $8-24-75$ & $7.07^{a}$ & $10.08^{b}$ & $10.27^{\mathrm{b}}$ & $12.84^{\mathrm{c}}$ & $11.25^{b}$ \\
\hline $9-27-75$ & $6.02^{\mathrm{a}}$ & $8.61^{\mathrm{b}}$ & $8.83^{b c}$ & $10.83^{d}$ & $10.13^{\text {cd }}$ \\
\hline $10-11-75$ & $5.68^{\mathrm{A}}$ & $8.13^{\mathrm{b}}$ & $8.50^{b}$ & $9.87^{\circ}$ & $9.02^{b c}$ \\
\hline $11-22-75$ & $5.81^{\mathrm{a}}$ & $8.26^{b}$ & $8.5 t^{b}$ & $10.29^{c}$ & $9.38^{\mathrm{bc}}$ \\
\hline $4-3-76$ & $6.52^{\mathrm{a}}$ & $9.70^{b}$ & $10.39^{b}$ & $12.27^{c}$ & $10.70^{\mathrm{b}}$ \\
\hline $5-1-76$ & $6.69^{a}$ & $10.95^{\mathrm{b}}$ & $12.13^{\mathrm{bc}}$ & $13.75^{\circ}$ & $11.92^{b}$ \\
\hline $6-6-76$ & $6.86^{\mathrm{a}}$ & $10.36^{\mathrm{b}}$ & $10.51^{\mathrm{b}}$ & $12.57^{\circ}$ & $10.69^{b}$ \\
\hline $6-20-76$ & $6.48^{\mathrm{a}}$ & $9.35^{b}$ & $9.73^{b}$ & $11.91^{\mathrm{b}}$ & $10.24^{b}$ \\
\hline $7-6-76$ & $6.43^{\mathrm{a}}$ & $9.10^{b}$ & $9.31^{b}$ & $11.88^{c}$ & $10.07^{b}$ \\
\hline $7-25-76$ & $6.33^{\mathrm{a}}$ & $8.88^{b}$ & $9.15^{b}$ & $11.48^{\circ}$ & $9.50^{b}$ \\
\hline $8-9-76$ & $6.5 T^{\circ}$ & $9.39^{b}$ & $9.75^{b}$ & $12.01^{\mathrm{c}}$ & $9.89^{\mathrm{b}}$ \\
\hline $8-23-76$ & $6.51^{\mathrm{a}}$ & $9.00^{\mathrm{b}}$ & $9.42^{b}$ & $11.30^{c}$ & $9.72^{\mathrm{bc}}$ \\
\hline $9-5-76$ & $6.46^{\circ}$ & $8.82^{b}$ & $9.07^{b}$ & $11.04^{\circ}$ & $9.34^{h}$ \\
\hline $9-20-76$ & $6.32^{\mathrm{a}}$ & $8.64^{b}$ & $9.00^{b}$ & $11.1 \gamma^{c}$ & $9.50^{b}$ \\
\hline $11-3-76$ & $5.81^{\mathrm{a}}$ & $8.20^{b}$ & $8.45^{b}$ & $10.68^{c}$ & $9.12^{\mathrm{bc}}$ \\
\hline $12-17-76$ & $6.08^{\mathrm{a}}$ & $8.58^{\mathrm{b}}$ & $9.12^{b}$ & $10.82^{c}$ & $9.02^{b}$ \\
\hline $2-4-77$ & $6.21^{\mathrm{a}}$ & $8.94^{\mathrm{b}}$ & $9.22^{\mathrm{b}}$ & $11.25^{\circ}$ & $9.41^{\mathrm{b}}$ \\
\hline
\end{tabular}

'All values in same row with same superscript are not significantly different at .05 level of probability.

${ }^{2}$ No grazing since 1967

${ }^{3}$ Crested wheatgrass utilized $55 \%$ during spring of $1974 ; 78 \%$ during spring of 1975 ; $66 \%$ during spring of 1976 .

${ }^{4}$ No grazing since treatments installed in 1967.

${ }^{5}$ Burning in fall, 1974; no grazing since chaining treatments installed in 1967 and no grazing following burning.

ungrazed windrowed treatment and the unburned debris-in-place treatment disappeared, with comparisons remaining essentially the same throughout the balance of the study. The reason for this change is not clear, but it may have been related to winter climatic conditions and snowfall patterns. A series of mild winters with reduced snowfall and higher temperatures could have resulted in less of a differential catch in moisture between the windrowed and debris-in-place treatments. Transpirational losses from surviving pinyon-juniper trees on the debris-in-place treatment would also have increased.

Through the summer of 1973 , the ungrazed windrowed treatment continued to display a pattern of increased soil water accumulation through the fall and winter periods. By late summer, however, its soil moisture patterns were similar to those found in the woodland. After 1973 the pattern changed, and in 1974, 1975 and 1976 soil water readings were always greater under the windrowed treatment than under the woodland. Most of the increased moisture accumulation occurred at soil depths below $60 \mathrm{~cm}$. 


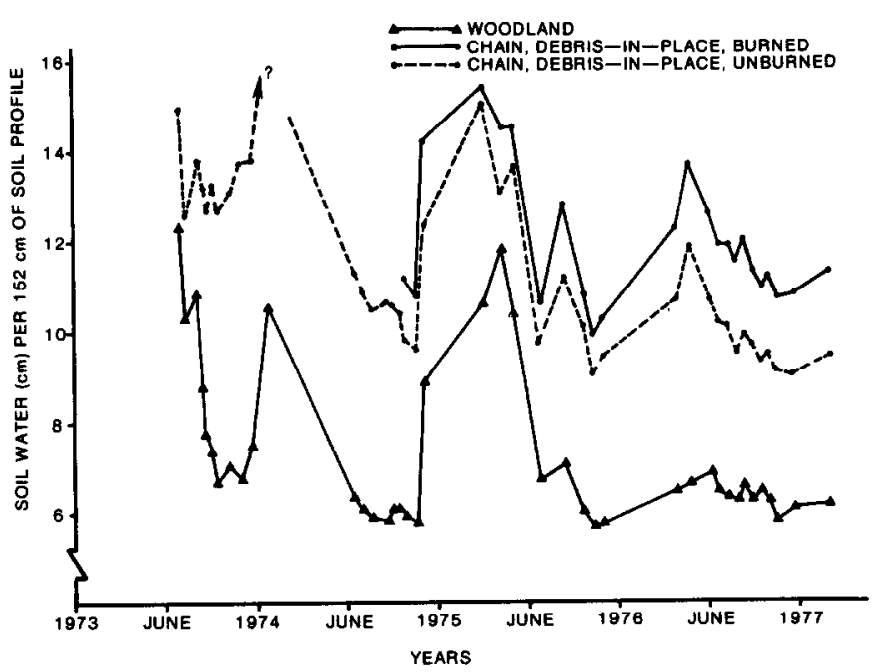

Fig. 2. Soil water patterns in native pinyon-juniper woodland and in burned and unburned chain with debris-in-place treatments.

Grazing did not affect soil water storage on the windrowed area, even though the crested wheatgrass on the area was utilized $55 \%$ to $78 \%$ each spring depending on the year. The lack of impact can probably be attributed to the initial low cover of the crested wheatgrass (maximum $25 \%$ canopy coverage). Under these condi- tions, grazing apparently does not alter evaporative conditions enough to modify soil water conditions.

Burning debris on the debris-in-place treatment had little effect on soil water accumulation the first year following burning. By the spring of the second year, however, significantly more moisture had accumulated under the burned treatment, and this trend continued throughout the remaining 17 months of the study. It would appear that the temporary effect of burning combined with seasonal growth (and transpiration) of the crested wheatgrass was sufficient to overcome the loss of debris piles (which reduce wind movement and provide mulch, both of which reduce the evaporation potential) on the burned area. In addition, as previously stated, the young pinyon and juniper trees that survived the chaining were transpiring year around on the unburned area. Assuming the burned sites behave in a manner similar to the windrowed area, however, this trend might easily be reversed with shifting climatic trends.

\section{Literature Cited}

Buckhouse, J.C., and G.F. Gifford. 1976. Sediment production and infiltration rates as affected by grazing and debris burning on chained and seeded pinyon-juniper. J. Range Manage. 29:83-85.

Gifford, G.F. 1975. Approximate annual water budgets of two chained pinyon-juniper sites. J. Range Manage. 28:73-74.

Gifford, G.F., and C.B. Shaw. 1973. Soil moisture patterns on two chained pinyon-juniper sites in Utah. J. Range Manage. 26:436-440.

Roundy, B.A., W.H. Blackburn, and R.E. Eckert, Jr. 1978. Influence of prescribed burning on infiltration and sediment production in the pinyon-juniper woodland, Nevada. J. Range Manage. 31:250-253.

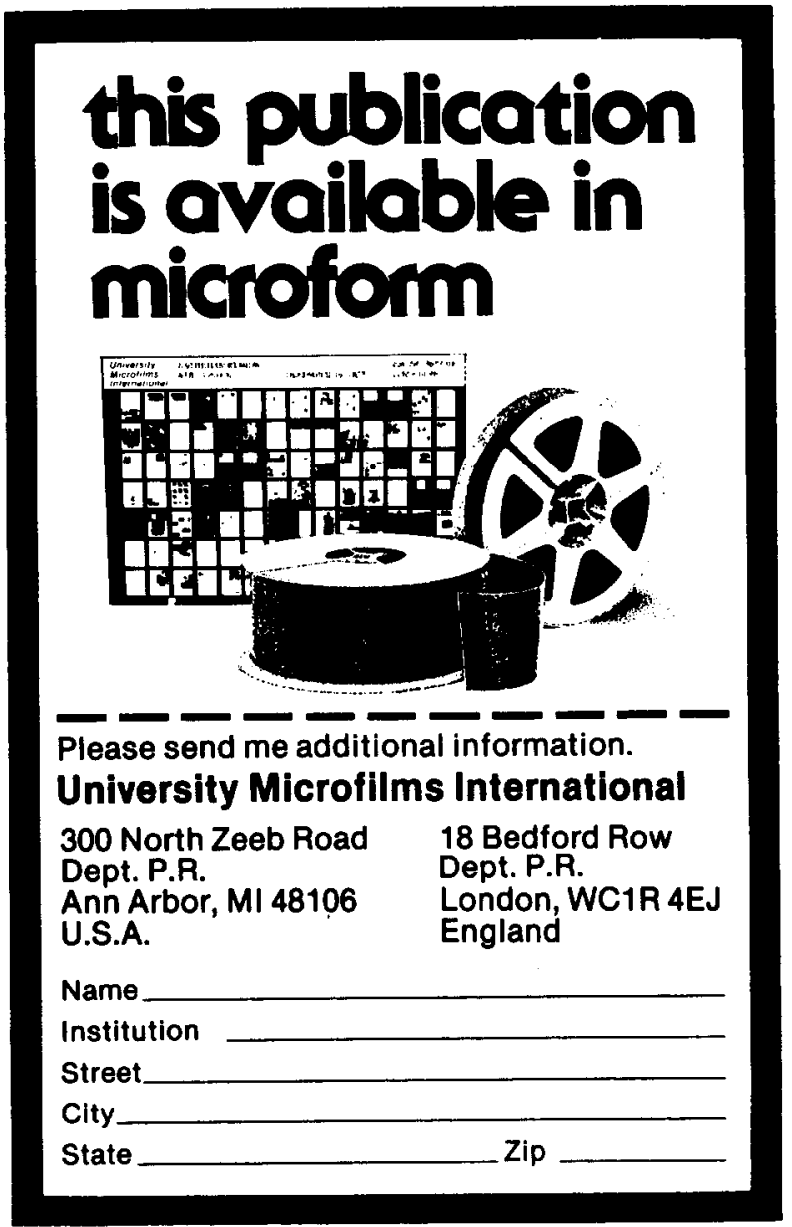

